\title{
The Influence of the Characteristics of Geomorphological Deposits on Terrestrial Plant Species Richness in the Low Flow Channel Downstream from an Inversion-Type Reservoir
}

\author{
Ali A Assani* and Sophie Leduc \\ Department of Environmental Sciences, University of Quebec at Trois-Rivières, Canada
}

Submission: May 14, 2021; Published: June 03, 2021

*Corresponding author: Ali A Assani, Department of Environmental Sciences, University of Quebec at Trois-Rivières, Trois-Rivières, 3351 Boulevard des Forges, Trois-Rivières, Québec G9A 5H7, Canada

Abstract

The article analyzes the influence of the characteristics (including grain size) of geomorphological deposits formed in the low flow channel downstream from a dam on the Matawin River $\left(5770 \mathrm{~km}^{2}\right)$ in Quebec. Since its construction in 1930, this dam has inverted the natural flow regime, with maximum flows occurring in winter and minimum flows in springtime, during snowmelt. A plant survey carried out in 2003 revealed that terrestrial plant species have become more abundant (46.2\%) than obligate wetland (28.4\%) and facultative-wetland (25.4\%) species in the low flow channel of the river downstream from the dam. Terrestrial species are more abundant on sandy deposits than on boulder deposits. They develop preferentially on stabilized geomorphological sandy and boulder deposits that were rarely flooded and are no longer reworked by stream current, and they are completely absent from annually flooded geomorphological deposits. The study suggests that, to stop the expansion of terrestrial species at the expense of wetland obligate species (a process called channel terrestrialization) downstream from the Matawin dam, high flows $\left(>400 \mathrm{~m}^{3} / \mathrm{s}\right)$ must be released each year in order to flood all geomorphological deposits accumulated in the low flow channel downstream from this dam.

Keywords: Terrestrial species; Obligate wetland species; Facultative-wetland species; Grain size of sediments; Geomorphological deposits; Inversion of the natural flow regime; dam

\section{Introduction}

Over 45,000 large dams (height $>15 \mathrm{~m}$ ) have been built around the world [1] since the $19^{\text {th }}$ century. These structures have altered the natural hydrologic regimes of rivers to various extents, as well as their morphological evolution and ecosystems. (e.g., [2-6]). In Quebec, over 500 large dams have been built, and three types of regulated hydrological regimes are observed downstream from these dams (e.g., $[7,8])$. The first of these (natural-type regulated regime) is characterized by the occurrence of maximum flows in the spring during snowmelt, and minimum flows in winter or summer. This type of regulated hydrological regime differs from hydrological regimes in natural rivers in that it shows a slight increase in flows in winter and a slight decrease in flows in springtime. This regime accounts for about $40 \%$ of all dams. The second type of regulated hydrological regime (homogenizationtype regulated regime), which accounts for about $20 \%$ of large dams, is characterized by flows that remain nearly constant year round. Finally, the third type of regulated regime (inversion-type regulated regime), which accounts for roughly $40 \%$ of large dams, is characterized by the occurrence of maximum flows in winter and minimum flows in the spring during snowmelt. The annual cycle of streamflow is thus inverted compared to that observed in natural rivers.

Of these three regulated hydrological regimes, the last one, the inversion-type hydrologic regime, leads to a very large decrease in flows downstream from dams in spring and summer (growing season). Reduced flows downstream from dams leads to reduced channel width and/or depth (e.g., [4,916]). This channel contraction results from the gradual invasion of dried up low flow channels by vegetation consisting mainly of terrestrial plant species at the expense of obligate wetland species [17]. While flows are undoubtedly the main cause of this channel terrestrialization phenomenon, the morphological and sedimentological characteristics of the deposits also exert considerable influence on the spatial and temporal variability of low flow channel colonization by terrestrial species [12,18-20]. However, while there is an abundant literature focusing on the impacts of dams on vegetation (e.g., $[3,6,12,21]$ ), very few studies as of yet have looked at the influence of the morphological and 
sedimentological characteristics of deposits in low flow channels on the species richness in these channels (e.g., [18,19,22-24]). Assani et al. [22] found a relationship between species richness and the morphological evolution of deposits in a gravely channel downstream from a reservoir in Belgium. Like the other studies, this study did not look specifically at the terrestrialization phenomenon, that is how the morpho-sedimentological characteristics of geomorphological deposits might influence the spatial distribution of terrestrial plant species in the low flow channel of a stream subjected to a significant decrease in streamflow after construction of a dam.

In Quebec, as part of a project aimed at analyzing the influence of abiotic factors (flows and habitat) on the terrestrialization of low-flow channels downstream from inversion-type dams, Assani et al. [25] demonstrated that, downstream from the Matawin dam, which is characterized by an inversion of the annual hydrological cycle, the abundance of terrestrial species on sand bars of similar type is strongly influenced by flow variations. Thus, during the growing season (April to September) when water levels are relatively high, the number of terrestrial species decreases on these bars due to the relatively extensive period during which these sites are under water. Dubeau et al. [26], for their part, showed that the duration of immersion of islets in springtime downstream from the Matawin dam strongly influences the number of terrestrial species on these islets. Thus, when islets Methodology remain under water for long periods in springtime, as was the case in 2008 (La Niña year), the number of terrestrial species decreases markedly to be replaced by obligate wetland species. On some islets, terrestrial species disappeared completely after the 2008 spring freshet only to reappear after the major drought that occurred in 2010 (El ñino year). However, these two studies did not investigated at the long-term effects of this hydrologic inversion phenomenon on the terrestrial plant species richness (terrestrialization phenomenon) in the low flow channel of the Matawin River downstream from the Taureau reservoir and the impacts associated with variations in the morphological and grain-size characteristics of the sites (deposits). Given the above, the goals of the present study are twofold:

a) To see whether 60 years after construction of the Matawin dam in 1930, terrestrial plant species have become more abundant than obligate wetland species and facultative-wetland species in the low flow channel downstream from the dam as a result of the inversion of the natural hydrological cycle of flow (reduced flows and curtailing of the spring freshet during the growing season).

b) To see whether terrestrial plant species develop preferentially in some geomorphological deposits (sites) depending on their grain size and geomorphological evolution in the low flow channel downstream from the Taureau reservoir.

\section{Description of the Taureau reservoir}

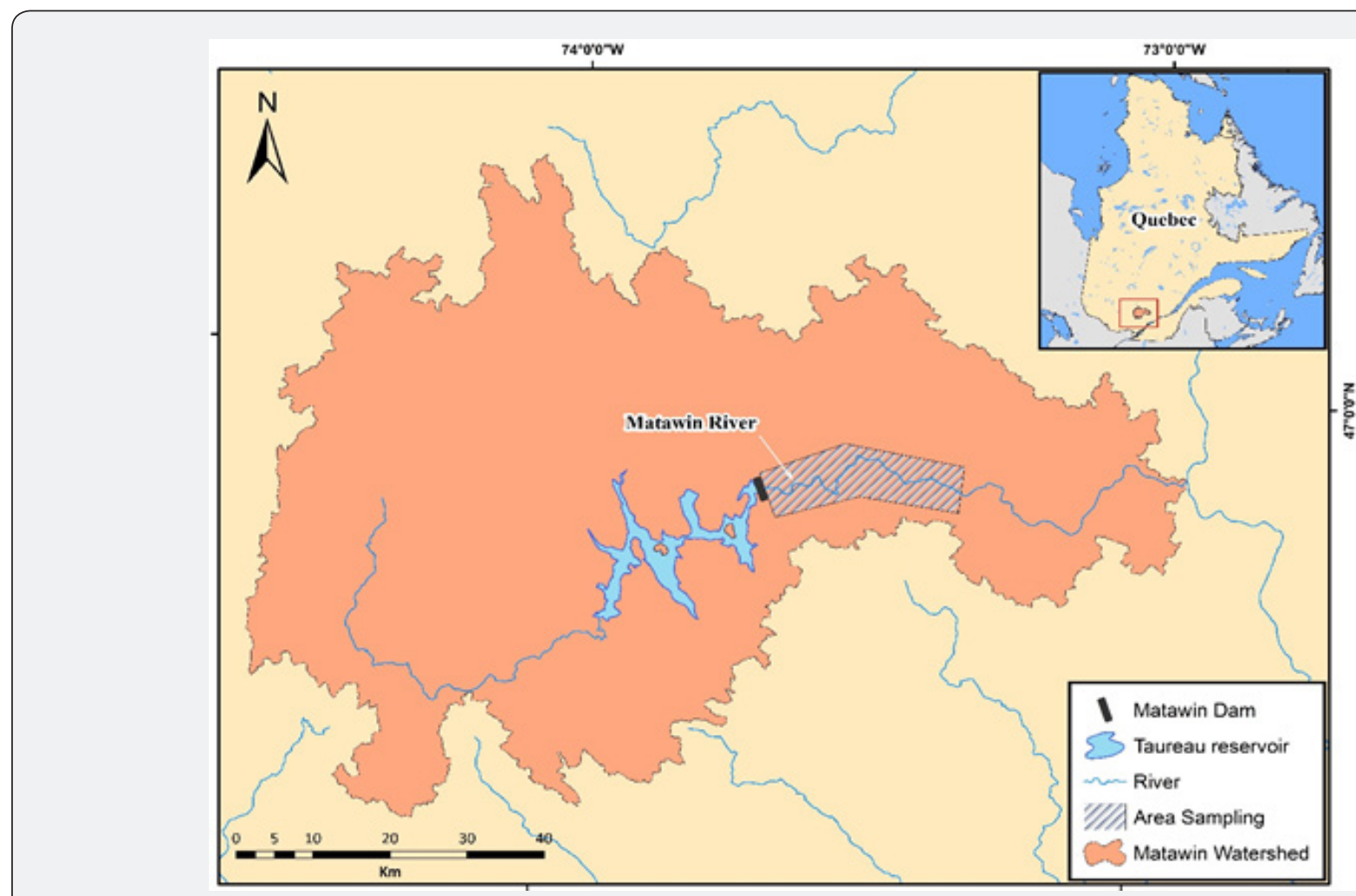

Figure 1: Matawin River watershed. Hashed area is where vegetation was sampled downstream from the dam. 
The Matawin River, which is the main tributary of the SaintMaurice River, drains a $5770-\mathrm{km}^{2}$ watershed, flowing entirely over the Canadian Shield along regularly alternating boulder, rocky, and sandy reaches (Figure 1). Due to their relatively strong slope, flow velocities are greater in boulder and rocky reaches than in sandy reaches. Climate in the region is of continental-subpolar type, with total annual precipitation on the order of $1000 \mathrm{~mm}$ (more than half falls as snow mainly from December to March) and a mean annual temperature of $4^{\circ} \mathrm{C}$. All of the watershed is located within the northern temperate vegetation zone, immediately south of the boreal zone, and lies for the most part in the Balsam Fir-Yellow Birch bioclimatic domain.

In 1930, the Shawinigan Power Company built a dam which impounded the Taureau reservoir. The Matawin dam is the gravity dam [27] which, at $720 \mathrm{~m}$ in length and $26 \mathrm{~m}$ in height, drains a $4070-\mathrm{km}^{2}$ area and has a total impoundment capacity of roughly $946,000,000 \mathrm{~m}^{3}$ [27]. It was built primarily to supply water in winter to hydroelectric power plants built.

Downstream along the Saint-Maurice River. In Quebec, because of the continental cold temperate climate, precipitation falls as snow in winter. For larger watersheds $\left(>1000 \mathrm{~km}^{2}\right)$, rivers generally start to freeze over in late December and thawing occurs in late April. To produce hydropower, numerous reservoirs have been built which store water derived from snowmelt in springtime and rainfall in summer, this water being released in winter to supply the hydroelectric power plants. This flow management mode, which has not changed since the dam was built despite the ownership change in 1962, has resulted in a complete inversion of the annual flow regime downstream from the dam in which, contrary to natural rivers, maximum flows occur in winter and minimum flows occur in springtime, during snowmelt (Figure 2). Several studies have provided a detailed description of this inversion phenomenon in Quebec [8,27-30].

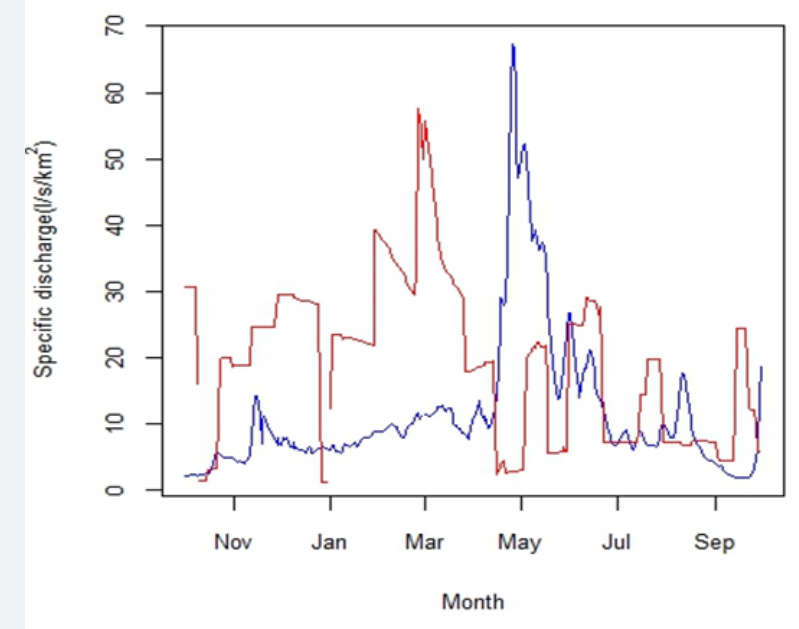

Figure 2: Comparison of specific discharge upstream (blue curve) and downstream (red curve) from the dam in 2003. The figure highlights the inversion of the natural cycle of flow downstream from the dam: maximum flows occur in winter and minimum flows, in springtime (complete disappearance of spring freshets) and summer (growing season).

Streamflow in the Matawin River has been measured continuously on a daily basis since 1930 at the Saint-Michel-desSaints station, located upstream from the dam, and at a station located immediately downstream from it. The dam does not affect streamflow upstream from it [28].

\section{Description of the characteristics of morphological deposits}

In light of field observations obtained since the summer of 2002, four types of deposits (are arranged from low to high inundation frequency) were identified on the Matawin River below and $40 \mathrm{~km}$ downstream from the Taureau reservoir based on grain size and stability:

a) Stabilized bank deposits: these sandy (S1) or boulder (B1) deposits were not affected by erosion by the river. No trace of erosion (fresh grooves) on these deposits or adjacent banks is visible in the field. In addition, they no longer undergo annual flooding during the growing season due to curtailing of the spring freshet downstream from the reservoir. The presence of plant debris and litter reflects the lack of any sediment reworking by current. Field observations show that these deposits are only flooded in very wet years when relatively large flows are released (flows $>400 \mathrm{~m}^{3} / \mathrm{s}$ ), downstream from the dam. Only five times over the period from 1931 to 2010 did flows reach or exceed such levels.

b) Deposits linked with slowing current: these sandy (S2) or boulder (B2) deposits are formed along curves or abruptly widening reaches. A sharp decrease in current velocity accounts for this type of deposit, which form bars and, as a result of their topographic position, are more frequently flooded during the growing season, although in very dry years they remain above water. These sites are flooded when flows released downstream 
from the dam are between $200 \mathrm{~m}^{3} / \mathrm{s}$ and $400 \mathrm{~m}^{3} / \mathrm{s}$. Such flows occurred on average every two to three years during the growing season (April to September) over the period from 1931 to 2010.

c) Confluence deposits: these deposits are formed at the confluence of tributaries (S3). Sandy sediments carried by tributaries accumulate in the Matawin River low flow channel as a result of the inversion of the hydrological regime by the Taureau reservoir. During snowmelt, water levels in the Matawin River decrease dramatically downstream from the reservoir due to water storage. This reduces the capacity of the river to transport and remove sediments brought in by tributaries. Unlike the former two types of deposits, confluence deposits are flooded annually by tributary inputs during the spring freshet. These sites are flooded by flows $<200 \mathrm{~m}^{3} / \mathrm{s}$ that occur every year.

d) Residual deposits: these comprise very coarse boulders that cannot be displaced (B3), and they were formed by hydrodynamic conditions different from those currently observed. These deposits are flooded when flows exceed $400 \mathrm{~m}^{3} / \mathrm{s}$.

\section{Sediment and plant sampling}

Sediment and plant sampling was conducted from May to Table 1: Geomorphological characterization of analyzed boulder (B) and sandy (S) deposits downstream from the dam as a function of the intensity of the frequency of their flooding during the growing season (April to September).

\begin{tabular}{|c|c|c|}
\hline Code & Type of Geomorphological Deposit & Intensity of Frequency of Annual Flooding \\
\hline B1 & Stabilized bank deposits & Rare $\left(\mathrm{Q}>400 \mathrm{~m}^{3} / \mathrm{s}\right)$ \\
\hline B2 & Deposits linked with slowing current (bars) & High (annual flooding) $\left(\mathrm{Q}<200 \mathrm{~m}^{3} / \mathrm{s}\right)$ \\
\hline B3 & Residual deposits & Moderate $\left(200 \mathrm{~m}^{3} / \mathrm{s}<\mathrm{Q}<400 \mathrm{~m}^{3} / \mathrm{s}\right)$ \\
\hline S1 & Stabilized bank deposits & Moderate $\left(200<\mathrm{Q}<400 \mathrm{~m}^{3} / \mathrm{s}\right)$ \\
\hline S2 & Deposits linked with slowing current (bars) & High (annual flooding) $\left(\mathrm{Q}<200 \mathrm{~m}^{3} / \mathrm{s}\right)$ \\
\hline S3 & Confluence deposits & High (annual flooding) $\left(\mathrm{Q}<200 \mathrm{~m}^{3} / \mathrm{s}\right)$ \\
\hline
\end{tabular}

As far as vegetation is concerned, a species inventory (presence only) was carried out at random on each deposit on fifty $1 \mathrm{~m} \times 1 \mathrm{~m}$ quadrats. The surface area of some deposits limited the number of quadrats. It is important to note that prior sampling carried out at three sites with different surface areas revealed that 50 quadrats were more than sufficient for a proper inventory of all species present in each site. This number also allowed for a thorough sampling, likely as a result of the limited number of species at each site $(<70)$. Plant species were identified in situ. However, when in situ identification was not possible, specimens were collected and identified in the laboratory with the help of recognized experts on southern Quebec plant taxonomy. The Laurentian flora nomenclature [33] was used to identify plant species. Once identified, species were divided into ecological groups based on the southern Quebec plant classification scheme proposed by the Ministère du Développement durable, de l'Environnement et des Parcs [34]. In this classification, species are subdivided into three ecological groups, namely:
September 2003 (growing season). For each type of deposit, three sites were sampled over a distance of $40 \mathrm{~km}$ downstream from the dam (Figure 1). The characteristics of the four types of deposits are summarized in Table 1. For sediment samples, roughly $300 \mathrm{~g}$ of sediments were collected in three different sites from the first $50 \mathrm{~cm}$ (same soil horizon) of each sandy deposit, taking care to remove roots and other organic material. The sites were selected at random, but at a sufficient distance from one another. These samples were then sent to the laboratory where they were dried for two days in a $105^{\circ} \mathrm{C}$ oven. After drying, grain-size analysis of $200 \mathrm{~g}$ of each sample was carried out by sieving to constrain the relative proportions of sand, silt and clay. For boulder deposits, the "largest constituent" method was used, which consists in measuring the intermediate axis of the largest boulders in order to estimate the average grain size of that deposit (e.g., [31,32]). In the present case, the intermediate axis (b-axis) was measured on the 30 largest pebbles. The choice of 30 pebbles is based on the fact that prior sampling revealed that the average values of intermediate axes obtained for 30 and 50 pebbles from a deposit were not statistically different at the $5 \%$ level. This comparison was made using the Kruskal-Wallis method and the Student $t$ test. a) Obligate wetland species (OBL): these are species that only grow in wetlands (e.g., Carex aquatilis, Carex versica, Equisetum fluviatile, Hypericum boreal, Juncus brevicaudatus, Glyceria strita, Potentilla palustris, etc.).

b) Facultative-wetland species (SWS): these are species that preferentially grow in wetlands, but can also occur in terrestrial settings (e.g., Hypericum Canadensis, Mentha Canadensis, Poa palustris, Juncus tenuis, Roripa islandica, etc.).

c) Terrestrial species (TERR): these species that can adapt to wetlands form the third category consisting of terrestrial species with broad ecological amplitude. Their number is unknown (e.g., Aralia nudicaulis, Betula alleghanensis, Fragaria Americana, Agrotis scabra, Panicum boreal, Viola septentrionalis, etc.).

The list of all species collected at the various sites is shown in Appendix 1. 


\section{Quantitative analysis}

To analyze grain size and plant species richness data, the following quantitative methods were used:

a) Analysis of variance using a single classification criterion (ANOVA) to compare relative proportions of sand, silt, and clay at sandy sites [35]. Each type of grain-size distribution was analyzed separately. The same method was used to compare the mean diameter (intermediate axis) of boulder deposits.

b) The classic chi-square method to compare the species richness in the three ecological groups of plants as a function of the nature and grain size of the deposits.

c) The classic Jaccard index to compare the degree of floristic resemblance between two sites (e.g., Dagnélie 1987).
The Jaccard index is an association coefficient that constrains the similarity between two individuals for binary absence/presence data.

\section{Results}

The proportions of sand, silt, and clay in the three types of sandy deposits are shown in Figure 3, from which it may be seen that the proportions of sand in S1 and S2 deposits are higher than in S3 deposits, while this latter type contains more silt than the other two. The proportion of clay is very small and similar for all three types of deposits. For boulder deposits (Figure 4), the B3 type is made up of larger constituents than the other two types, B1 and B2. Of the three types of boulder deposits, B2 comprises the smallest constituents.

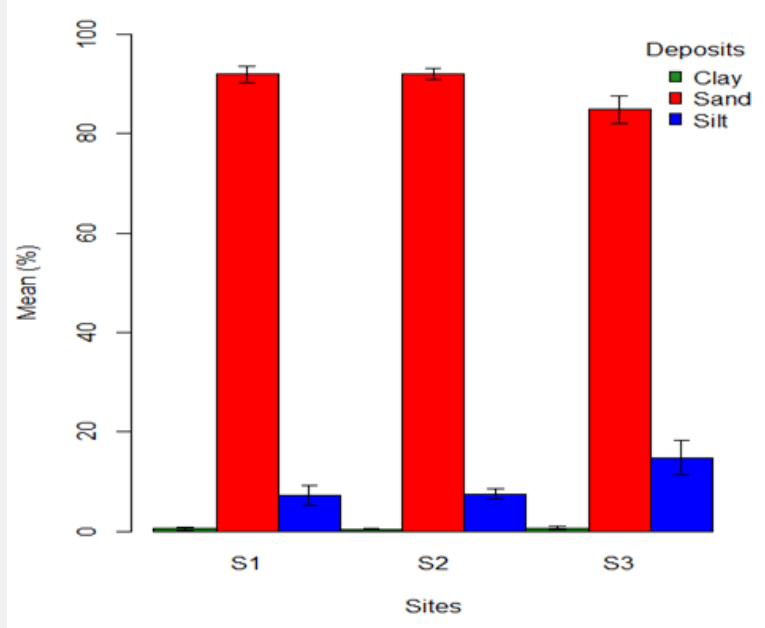

Figure 3: Comparison of clay, sand, and silt percentages in three types of sandy deposits downstream from the Taureau reservoir. B) Comparison of the mean diameter (average of 30 largest boulders) of three types of boulder deposits downstream from Taureau reservoir. For each type of deposit, 90 boulders were measured (three sites).

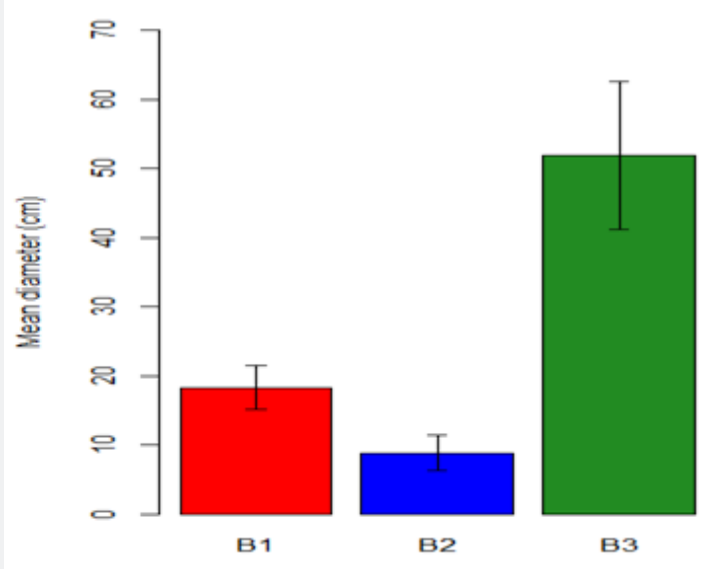

Figure 4: Comparison of the mean diameter (average of 30 largest boulders) of three types of boulder deposits downstream from Taureau reservoir. For each type of deposit, 90 boulders were measured (three sites). 
In the summer of 2003, 134 plant species were inventoried in total on the six types of geomorphological deposits sampled downstream from the dam. These 134 species included $38(28.4 \%)$ obligate wetland species, 34 (25.4\%) facultative-wetland species, and $62(46.2 \%)$ terrestrial species. The majority of plant species found on geomorphological deposits formed in the Matawin River low flow channel downstream from the dam are terrestrial. Of these 134 species, 105 (31 obligate wetlands species, 28 facultative-wetlands species, and 46 terrestrial species) were present on the three types of sandy deposits, and 80 species (23 obligate wetlands species, 25 facultative-wetlands species, and 32 terrestrial species) were observed on the three types of boulder deposits. Hence, the number of ecological terrestrial species was larger than the numbers observed in the other two ecological groups on both types of deposits.

Analysis of the relationship between geomorphological deposit

types and the number of plant species in three ecological groups using the chi-square method revealed a statistically significant correlation at the 5\% level (Khi-square score: 40.65 ; ddl: 16) between the two groups of variables (Table 2 and Figure 5). It is therefore possible to conclude with certainty that terrestrial species grow preferentially on stabilized bank deposits (B1 and S1). This preference is also observed on sandy deposits (Khisquare score: 27.35; ddl: 7). However, no terrestrial species was found on the S3 sandy deposit. If only boulder deposits are considered, however, this preference disappears. Thus, unlike for sandy deposits, the chi-square method suggested no significant difference between the three types of boulder deposits and the three groups of plant species (Khi-square score: 11.02; ddl: 7). It is important to note that no statistically significant relationship was found between distance to the dam and plant species richness (including terrestrial species). Hence, there is no longitudinal variation in the number of terrestrial species downstream from the Taureau reservoir.

\begin{tabular}{|l|l|} 
Figure 5: Comparison of abundance (total number) of species in the three ecological groups found on boulder (B1, B2, and B3) and sandy \\
(S1, S2, and S3) deposits downstream from Taureau reservoir. Blue bars: obligate wetland species; green bars: facultative-wetland species; \\
red bars: terrestrial species.
\end{tabular}

Table 2: Comparison of species richness in three ecological groups collected on different types of deposits in 2003.

\begin{tabular}{|c|c|c|c|c|}
\hline Deposit Types & Total & Obligate Wetland Species & Facultative-Wetland Species & Terrestrial Species \\
\hline B1 & 49 & 10 & 16 & 23 \\
\hline B2 & 31 & 14 & 12 & 5 \\
\hline B3 & 30 & 8 & 14 & 8 \\
\hline S1 & 81 & 19 & 21 & 10 \\
\hline S2 & 49 & 22 & 17 & 0 \\
\hline S3 & 23 & 14 & 9 & 41 \\
\hline
\end{tabular}

Finally, regarding the floristic similarity of the different geomorphological deposits, Table 3 shows that the mean value of Jaccard indices is less than $30 \%$. In other words, two different deposits have fewer than $30 \%$ species in common. More than half the species are specific to one type of deposit and no species was observed at all sites. The lowest Jaccard index value derived was between B1 and S3 deposits, and the highest value was between B2 and S2 deposits. 


\section{Discussion}

As far as the long-term effects of the inversion of the natural hydrological cycle downstream from the Taureau reservoir are concerned, a comparison of the species richness in three ecological groups revealed that the number of terrestrial species is higher (more than half of the species tallied in 2003) than the number of species in the other two ecological groups (obligate wetland and facultative-wetland species), despite the fact that the low flow channel is normally a wet setting and therefore not very hospitable to terrestrial species. It is the hydrologic inversion phenomenon that accounts for this presence of terrestrial species in much larger numbers than wetland and facultative-wetland species. This inversion results in the disappearance of the spring freshet and the maintenance of unusually low flows during the growing season (April to September). Moreover, in dry years, periods with no flow downstream from the dam are frequently observed which can sometimes last more than 100 consecutive days. As a result, a large portion of the low flow channel remains dry during the whole growing season, which, over time, promotes the gradual invasion of the channel by terrestrial plants (Figure 6), resulting in the gradual terrestrialization of the Matawin River channel downstream from the Taureau reservoir.

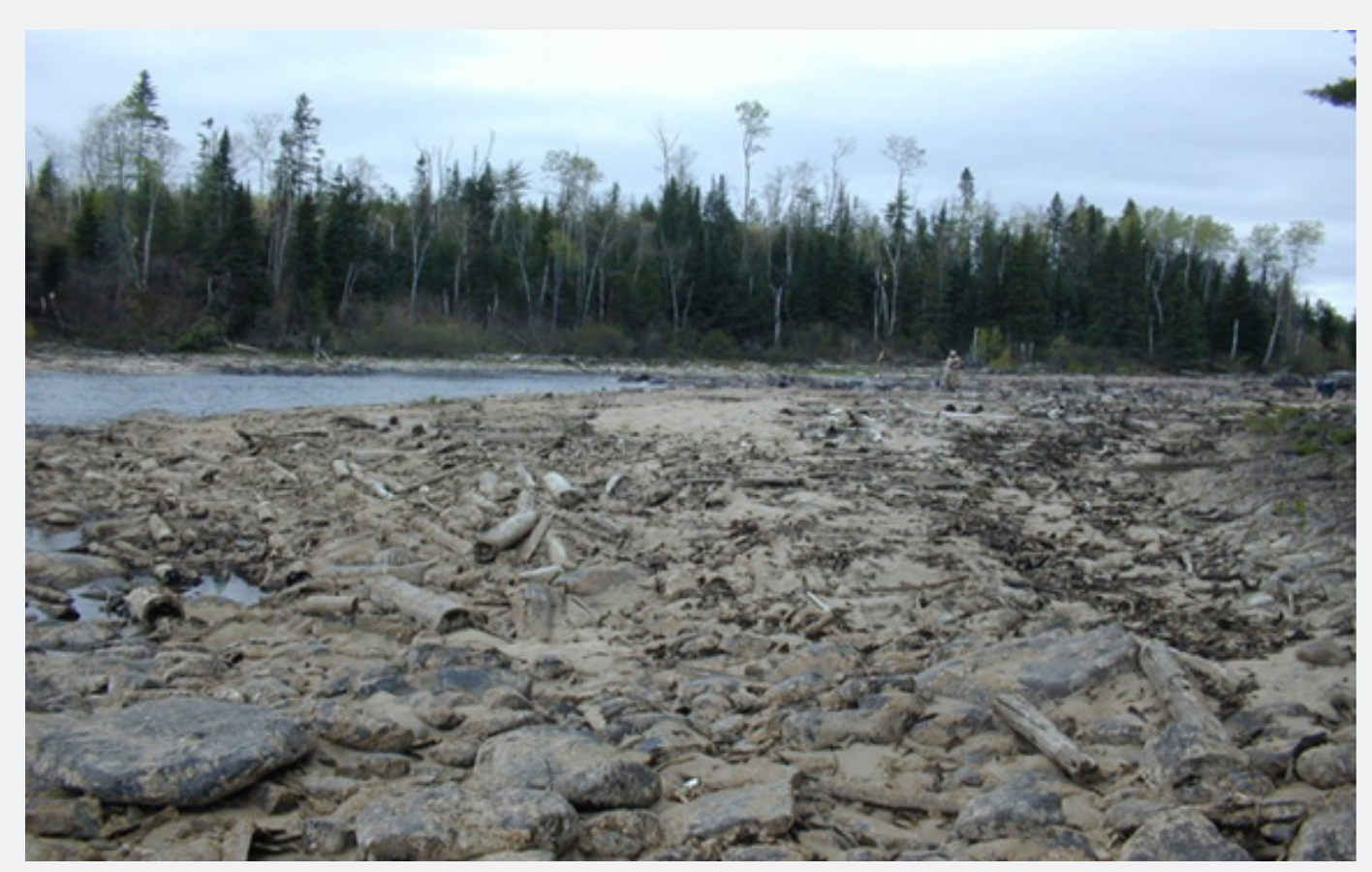

Figure 6: Exposure of the dry low flow channel of the Matawin River downstream from the dam in June 2003 favouring the invasion of terrestrial species. This drying of the channel is due to water storage in the reservoir resulting in intermittent flow downstream from the dam.

However, in the low flow channel, these terrestrial species appear to grow preferentially on some sites (deposits), and three factors - the grain size of geomorphological deposits, their morphological evolution, and the frequency of flooding of these deposits during the year - are interpreted to influence the nature of these preferred sites. As far as grain size is concerned, the relative proportion of species that are terrestrial is higher on sandy deposits (55\%) than on boulder deposits (45\%). The presence of fines promotes plant colonization on sandy deposits and the area of available habitat is much larger [22-24]. As far as the morphological evolution of the deposits is concerned, stabilized sandy and boulder deposits show larger numbers of terrestrial plant species than the other types of deposits; the lower likelihood of sediment erosion or accumulation on these deposits allows plant establishment and persistence. Finally, as far as the frequency of flooding of the deposits is concerned, terrestrial plants are absent from annually flooded sites, such as confluence deposit sites which are flooded annually by tributaries, even though the Matawin dam curtails the spring freshet. This annual flooding prevents terrestrial plants from colonizing these sites [25].

Jaccard index values derived between the different types of deposits were generally very low $(<30 \%)$, indicating that species tend to colonize only one type of deposits. These low Jaccard index values also suggest that the geomorphological nature of the deposit has a much greater influence on the presence of a species at a given site than the grain size of the deposit. This could likely be due to the heterogeneous nature of the components of these deposits. This heterogeneity could influence seed sprouting and the establishment of seedlings on these deposits. 


\section{Conclusion}

With a view to limit terrestrialization (invasion by terrestrial species) of the Matawin River channel downstream from the dam, flow releases high enough to flood the whole channel (> $400 \mathrm{~m}^{3} / \mathrm{s}$ ) should be carried out every year to prevent the gradual invasion of terrestrial plants at the expense of obligate wetland species. This suggestion is based on observations of plants on islets downstream from the dam from 2006 to 2011. During the 2008 growing season (April to September), there were many days

\section{Appendix}

Annex: List of species.

\begin{tabular}{|c|c|c|c|c|c|c|c|c|}
\hline \multicolumn{9}{|c|}{ Obligate Wetland Species } \\
\hline & Name of Species & B1 & B2 & B3 & S1 & S2 & S3 & TNS \\
\hline Present on 6 deposits & & & & & & & & 0 \\
\hline \multirow{4}{*}{ Present on 5 deposits } & Carex aquatilis l & $\mathrm{x}$ & $\mathrm{x}$ & $\mathrm{x}$ & $\mathrm{x}$ & $\mathrm{x}$ & & \multirow{4}{*}{4} \\
\hline & Lycopus americanus & & $\mathrm{x}$ & $\mathrm{x}$ & $\mathrm{x}$ & $\mathrm{x}$ & $\mathrm{x}$ & \\
\hline & Polygonum hydropiper & & $\mathrm{x}$ & $\mathrm{x}$ & $\mathrm{x}$ & $\mathrm{x}$ & $\mathrm{x}$ & \\
\hline & Sium suave & $\mathrm{x}$ & $\mathrm{x}$ & $\mathrm{x}$ & & $\mathrm{x}$ & $\mathrm{x}$ & \\
\hline \multirow{5}{*}{ Present on 4 deposits } & Carex versicaria & $\mathrm{x}$ & & & $\mathrm{x}$ & $\mathrm{x}$ & $\mathrm{x}$ & \multirow{5}{*}{5} \\
\hline & Equisetum fluviatile & $\mathrm{x}$ & $\mathrm{x}$ & & $\mathrm{x}$ & $\mathrm{x}$ & & \\
\hline & Hypericum virginicum & & $\mathrm{x}$ & & $\mathrm{x}$ & $\mathrm{x}$ & $\mathrm{x}$ & \\
\hline & Lycopus uniflorus & $\mathrm{x}$ & & & $\mathrm{x}$ & $\mathrm{x}$ & $\mathrm{x}$ & \\
\hline & Véronica scutellata & & $\mathrm{x}$ & & $\mathrm{x}$ & $\mathrm{x}$ & $\mathrm{x}$ & \\
\hline \multirow{5}{*}{ Present on 3 deposits } & Hypericum boreal & & $\mathrm{x}$ & & $\mathrm{x}$ & $\mathrm{x}$ & & \multirow{5}{*}{5} \\
\hline & Iris versicolor & $\mathrm{x}$ & & & $\mathrm{x}$ & $\mathrm{x}$ & & \\
\hline & Lysimachia terrestris & & $\mathrm{x}$ & & $\mathrm{x}$ & & $\mathrm{x}$ & \\
\hline & Mimulus ringens & & & & $\mathrm{x}$ & $\mathrm{x}$ & $\mathrm{x}$ & \\
\hline & Viola pallens & $\mathrm{x}$ & & $\mathrm{x}$ & & $\mathrm{x}$ & & \\
\hline \multirow{8}{*}{ Present on 2 deposits } & Chelone glabra & & $\mathrm{x}$ & & $\mathrm{x}$ & & & \multirow{8}{*}{8} \\
\hline & Glyceria borealis & & $\mathrm{x}$ & $\mathrm{x}$ & & & & \\
\hline & Glyceria (canadense) canadensis & & & & & $\mathrm{x}$ & $\mathrm{x}$ & \\
\hline & Juncus brevicaudatus & & $\mathrm{x}$ & & & & $\mathrm{x}$ & \\
\hline & Myrica gale & $\mathrm{x}$ & $\mathrm{x}$ & & & & & \\
\hline & Sagittaria latifolia & & & & & $\mathrm{x}$ & $\mathrm{x}$ & \\
\hline & Scirpus actrocintus & & & & $\mathrm{x}$ & $\mathrm{x}$ & & \\
\hline & Scirpus cyperinus & & & & $\mathrm{x}$ & $\mathrm{x}$ & & \\
\hline \multirow{10}{*}{ Present on 1 deposits } & Acer saccharinum & $\mathrm{x}$ & & & & & & \multirow{10}{*}{16} \\
\hline & Eleocharis acicularis & & & & $\mathrm{x}$ & & & \\
\hline & Eleocharis smallii & & & & & $\mathrm{x}$ & & \\
\hline & Eriocaulon septangulare & & & & & & $\mathrm{x}$ & \\
\hline & Glyceria ferna(n)ldii & & & $\mathrm{x}$ & & & & \\
\hline & Glyceria grandis & & & $\mathrm{x}$ & & & & \\
\hline & Glyceria septentrionalis & & & & $\mathrm{x}$ & & & \\
\hline & Glyceria striata & & & & $\mathrm{x}$ & & & \\
\hline & Polygonum sagittatum & & & & & & $\mathrm{x}$ & \\
\hline & Potentilla palustris & & & & & $\mathrm{x}$ & & \\
\hline
\end{tabular}

when relatively large flows $\left(>100 \mathrm{~m}^{3} / \mathrm{s}\right)$ were released [36], such that islets remained submerged during this high flow period. This prolonged immersion led to the near disappearance of terrestrial species on the islets the following year [26]. This clearly shows that the duration of immersion of sites significantly affects the number of terrestrial species. It follows that the suppression of spring flooding should promote the expansion of islets on the low-flow channel of the Matawin River downstream from the dam. Reestablishing spring flood flows could therefore limit this expansion. 
International Journal of Environmental Sciences \& Natural Resources

\begin{tabular}{|c|c|c|c|c|c|c|c|c|}
\hline \multirow{6}{*}{ Present on 1 deposits } & Rhamnus alnifolia(us) & $\mathrm{x}$ & & & & & & \multirow{6}{*}{16} \\
\hline & Scirpus rubrot(c)inctus & & & & & $x$ & & \\
\hline & Scirpus sp. & & & & & $\mathrm{x}$ & & \\
\hline & Scutellaria epilobifolia & & & & & $\mathrm{x}$ & & \\
\hline & Scutellaria lateriflora & & $\mathrm{x}$ & & & & & \\
\hline & Torreyochloa pallida & & & & $\mathrm{x}$ & & & \\
\hline \multicolumn{9}{|c|}{ Semi-Wetland Species } \\
\hline Present on 6 deposits & Ranunculus reptans & $\mathrm{x}$ & $\mathrm{x}$ & $\mathrm{x}$ & $\mathrm{x}$ & $\mathrm{x}$ & $\mathrm{x}$ & 1 \\
\hline \multirow{6}{*}{ Present on 5 deposits } & Aster puniceus & & $\mathrm{x}$ & $\mathrm{x}$ & $\mathrm{x}$ & $\mathrm{x}$ & $\mathrm{x}$ & \multirow{6}{*}{6} \\
\hline & Carex crinita & & $\mathrm{x}$ & $\mathrm{x}$ & $\mathrm{x}$ & $\mathrm{x}$ & $\mathrm{x}$ & \\
\hline & Eupatorium maculatum & $\mathrm{x}$ & $\mathrm{x}$ & $\mathrm{x}$ & $\mathrm{x}$ & $\mathrm{x}$ & & \\
\hline & Gal(I)ium pal(I)ustre L. & & $\mathrm{x}$ & $\mathrm{x}$ & $\mathrm{x}$ & $x$ & $\mathrm{x}$ & \\
\hline & Hypericum canadense & $\mathrm{x}$ & $\mathrm{x}$ & $\mathrm{x}$ & $\mathrm{x}$ & $\mathrm{x}$ & & \\
\hline & Thalictrum pubescens & $\mathrm{x}$ & $\mathrm{x}$ & $\mathrm{x}$ & $\mathrm{x}$ & $\mathrm{x}$ & & \\
\hline Present on 4 deposits & Juncus filiformis & $\mathrm{x}$ & $\mathrm{x}$ & & $\mathrm{x}$ & $\mathrm{x}$ & & 1 \\
\hline \multirow{9}{*}{ Present on 3 deposits } & Acer rubrum & & $\mathrm{x}$ & $\mathrm{x}$ & & & $\mathrm{x}$ & \multirow{9}{*}{9} \\
\hline & Agrotis alba L. & & $\mathrm{x}$ & & $\mathrm{x}$ & & $\mathrm{x}$ & \\
\hline & Alnus rugosa & $\mathrm{x}$ & & & $\mathrm{x}$ & $\mathrm{x}$ & & \\
\hline & Aster umbellatus & $\mathrm{x}$ & & $\mathrm{x}$ & $\mathrm{x}$ & & & \\
\hline & Calamagrotis canadensis(e) & & & & $\mathrm{x}$ & $\mathrm{x}$ & $\mathrm{x}$ & \\
\hline & Carex scoparia & & $\mathrm{x}$ & $\mathrm{x}$ & $\mathrm{x}$ & & & \\
\hline & Poa palustris & $\mathrm{x}$ & & $\mathrm{x}$ & & $\mathrm{x}$ & & \\
\hline & Salix discolor & $\mathrm{x}$ & & $\mathrm{x}$ & & $\mathrm{x}$ & & \\
\hline & Salix rigida & $\mathrm{x}$ & & & & $\mathrm{x}$ & $\mathrm{x}$ & \\
\hline \multirow{5}{*}{ Present on 2 deposits } & Cornus stolonifera & $\mathrm{x}$ & & & $\mathrm{x}$ & & & \multirow{5}{*}{5} \\
\hline & Mentha Canadensis & & & & $\mathrm{x}$ & $\mathrm{x}$ & & \\
\hline & Onoclea sensibilis & & & & $\mathrm{x}$ & & $\mathrm{x}$ & \\
\hline & Salix bebbiana sp. & $\mathrm{x}$ & & & $\mathrm{x}$ & & & \\
\hline & Scirpus a(n)trovirens & $\mathrm{x}$ & & & & $\mathrm{x}$ & & \\
\hline \multirow{12}{*}{ Present on 1 deposits } & Impatiens capensis & & & & $\mathrm{x}$ & & & \multirow{12}{*}{12} \\
\hline & Juncus tenius & & & & $\mathrm{x}$ & & & \\
\hline & Larix laricina & $\mathrm{x}$ & & & & & & \\
\hline & Lythrum salicaria & & & & & $\mathrm{x}$ & & \\
\hline & Muhlenbergia glomerata & & & $\mathrm{x}$ & & & & \\
\hline & Osmunda cinnamomea & $\mathrm{x}$ & & & & & & \\
\hline & Osmunda regalis & & & $\mathrm{x}$ & & & & \\
\hline & Populus balsamifera & $\mathrm{x}$ & & & & & & \\
\hline & Populus deltoides & & & & $\mathrm{x}$ & & & \\
\hline & Roripa islandica & & $\mathrm{x}$ & & & & & \\
\hline & Salix lucida & & & & & $\mathrm{x}$ & & \\
\hline & Viburnum cassinoides & & & & $\mathrm{x}$ & & & \\
\hline \multicolumn{9}{|c|}{ Terrestrial Species } \\
\hline Present on 6 settings & & & & & & & & 0 \\
\hline
\end{tabular}


International Journal of Environmental Sciences \& Natural Resources

\begin{tabular}{|c|c|c|c|c|c|c|c|}
\hline \multirow{2}{*}{ Present on 5 deposits } & Solidago graminifolia & $\mathrm{x}$ & $\mathrm{x}$ & $x$ & $x$ & $\mathrm{x}$ & \multirow{2}{*}{2} \\
\hline & Spirea latifolia & $\mathrm{x}$ & $\mathrm{x}$ & $\mathrm{x}$ & $\mathrm{x}$ & $\mathrm{x}$ & \\
\hline Present on 4 deposits & & & & & & & 0 \\
\hline \multirow{2}{*}{ Present on 3 depositis } & Anaphalis margaritaceae & $\mathrm{x}$ & & & $\mathrm{x}$ & $\mathrm{x}$ & \multirow{2}{*}{2} \\
\hline & Fragaria americana & $\mathrm{x}$ & & & $\mathrm{x}$ & $\mathrm{x}$ & \\
\hline \multirow{15}{*}{ Present on 2 depositis } & Acer pensylvanicum & $\mathrm{x}$ & & & $\mathrm{x}$ & & \multirow{15}{*}{15} \\
\hline & Agrotis scabra & & & & $\mathrm{x}$ & $\mathrm{x}$ & \\
\hline & Apocynum androseamifolium & $\mathrm{x}$ & & & $\mathrm{x}$ & & \\
\hline & Aster cordifolius & & & $\mathrm{x}$ & $\mathrm{x}$ & & \\
\hline & Betula papyrifera & $\mathrm{x}$ & & & $\mathrm{x}$ & & \\
\hline & Corylus cornuta & $\mathrm{x}$ & & & $\mathrm{x}$ & & \\
\hline & Diervilla lonicera & $\mathrm{x}$ & & & $\mathrm{x}$ & & \\
\hline & Erigeron strigosus & $\mathrm{x}$ & & & & $\mathrm{x}$ & \\
\hline & Hieracium aurantiacum & $\mathrm{x}$ & & & $\mathrm{x}$ & & \\
\hline & Panicum boreal & & & $\mathrm{x}$ & $\mathrm{x}$ & & \\
\hline & Pinus divaricata & $\mathrm{x}$ & & & $\mathrm{x}$ & & \\
\hline & Populus tremuloides & $\mathrm{x}$ & & & $\mathrm{x}$ & & \\
\hline & Rubus idaeus & $\mathrm{x}$ & & & $\mathrm{x}$ & & \\
\hline & Vaccinum myrtilloides & $\mathrm{x}$ & & & $\mathrm{x}$ & & \\
\hline & Viola septentrionalis & & $\mathrm{x}$ & & $\mathrm{x}$ & & \\
\hline \multirow{24}{*}{ Present on 1 deposit } & Abies balsamifera & $\mathrm{x}$ & & & & & \multirow{24}{*}{41} \\
\hline & Acer spicatum & & & & $\mathrm{x}$ & & \\
\hline & Achillea millefolium & & & & $\mathrm{x}$ & & \\
\hline & Amélanchier wiegandii & & & & $\mathrm{x}$ & & \\
\hline & Amélanchier sp. & & & & $\mathrm{x}$ & & \\
\hline & Anemone canadense & & & & & $\mathrm{x}$ & \\
\hline & Aralia nudicaulis & & & & $\mathrm{x}$ & & \\
\hline & Aster acuminatus & & $\mathrm{x}$ & & & & \\
\hline & Aster macrophyllus & & & & $\mathrm{x}$ & & \\
\hline & Aster novie-belgii & & & $\mathrm{x}$ & & & \\
\hline & Athyrium filix-femina & & & & $\mathrm{x}$ & & \\
\hline & Betula alleghanensis & & & & $\mathrm{x}$ & & \\
\hline & Carex convulata & & & $\mathrm{x}$ & & & \\
\hline & Carex communis & & & & $\mathrm{x}$ & & \\
\hline & Clematis virginiana & & & $\mathrm{x}$ & & & \\
\hline & Cornus alternifolia & $\mathrm{x}$ & & & & & \\
\hline & Épilobium angustifolium & $\mathrm{x}$ & & & & & \\
\hline & Habenaria fimbriata & & & & $\mathrm{x}$ & & \\
\hline & Linnaea borealis & $\mathrm{x}$ & & & & & \\
\hline & Maianthenum canadense & & & & $\mathrm{x}$ & & \\
\hline & Oxalis stricta & & & & & $\mathrm{x}$ & \\
\hline & Phleum pratense & & $\mathrm{x}$ & & & & \\
\hline & Picea glauca & $\mathrm{x}$ & & & & & \\
\hline & Pinus resinosa & $\mathrm{x}$ & & & & & \\
\hline
\end{tabular}




\section{International Journal of Environmental Sciences \& Natural Resources}

\begin{tabular}{|c|c|c|c|c|c|c|}
\hline \multirow{17}{*}{ Present on 1 deposit } & Pinus strobes & & $\mathrm{x}$ & & & \multirow{17}{*}{41} \\
\hline & Plantago major & & & & $\mathrm{x}$ & \\
\hline & Polygonum cilinode & & & $\mathrm{x}$ & & \\
\hline & Polygonum convulvus & & & $\mathrm{x}$ & & \\
\hline & Potentilla norvegica & $\mathrm{x}$ & & & & \\
\hline & Prunus pensylvanica & $\mathrm{x}$ & & & & \\
\hline & Pteridium aquilinum & & & $\mathrm{x}$ & & \\
\hline & Pyrola elliptica & & & $\mathrm{x}$ & & \\
\hline & Salix humilis & & & $\mathrm{x}$ & & \\
\hline & Solidago canadense & & & & $\mathrm{x}$ & \\
\hline & Solidago macrophylla & & & $\mathrm{x}$ & & \\
\hline & Solidago puberla & & & $\mathrm{x}$ & & \\
\hline & Solidago rugosa & & & $\mathrm{x}$ & & \\
\hline & Sorbus americana & & & $\mathrm{x}$ & & \\
\hline & Steptopus roseus & & & $\mathrm{x}$ & & \\
\hline & Taraxacum officinale & & & $\mathrm{x}$ & & \\
\hline & Vicia cracca & & & $\mathrm{x}$ & & \\
\hline
\end{tabular}

$X=$ presence $;$ TNS $=$ Total number of species

\section{References}

1. Nilsson C, Reidy CA, Dynesius M, Revenga C (2005) Fragmentation and flow regulation of the world's large river systems. Science 308(5720): 405-408.

2. Bunn ES, Arthington AH (2002) Basic principles and ecological consequences of altered flow regimes for aquatic biodiversity. Env Manage 30(4): 492-507.

3. Nilsson C, Svedmark M (2002) Basic principles and ecological consequences of changing water regimes: Riparian plant. Environ Manage 30: 468-480.

4. Petts GE (1979) Complex response of river channel morphology subsequent to reservoir construction. Progr Phys Geogr 3(3): 329-362.

5. Pinay G, Clément JC, Naiman RJ (2002) Basic principles and ecological consequences of changing water regimes on nitrogen cycling in fluvial systems. Env Manage 30: 481-491.

6. Poff NL, Allan JD, Bain MB, Karr JR, Prestegaard KL, et al. (1997) The natural flow regime. A paradigm for river conservation and restoration. Bioscience 47(11): 769-784.

7. Poff NL, Julie K, Zimmerman KH (2010) Ecological responses to altered flow regimes: A literature review to inform the science and management of environmental flows. Freshw Biol 55(1): 194-205.

8. Matteau M, Assani AA, Mesfioui M (2009) Application of multivariate statistical analysis methods to the dam hydrologic impact studies. J Hydrol 371(1-4): 120-128

9. Brandt SA (2000a) Classification of geomorphological effects downstream of dams. Catena 40: 375-401.

10. Csiki S, Rhoads BL (2010) Hydraulic and geomorphological effects of run-of-river dams. Progr Phys Geogr 34(6): 755-780.

11. Graf WL (2006) Downstream hydrologic and geomorphologic effects of large dams on America rivers. Geomorph 79(3-4): 336-360.

12. Ligon FK, Dietrich WE, Trush WJ (1995) Downstream ecological effects of dams. Bioscience 45(3): 183-192.

13. Petts GE, Gurnell AM (2005) Dams and geomorphology: Research progress and future directions. Geomorph 71(1-2): 27-47

14. Radoane M, Radoane N (2005) Dams, sediment sources and reservoir silting in Romania. Geomorph 71(1-2): 112-125.

15. William GP, Wolman G (1984) Dowsntream effects of dams on alluvial rivers. Geological Survey Professional Paper no 1286, p. 83.

16.Xu J (1990) An experimental study of complex response in river channel adjustment downstream from a reservoir. Earth Process Landforms 15(1): 43-53.

17. Kondolf GM, Piégay H (2003) Tools in fluvial geomorphology. Wiley, Wiltshire, p. 688.

18. Bernez I, Daniel H, Ferreira MT (2004) Combined effect of environmental factors and regulation on macrophyte vegetation along three rivers in western France. River Res Applic 20(1): 43-59.

19. Riis T, Sand Jensen K, Larsen SE (2001) Plant distribution and abundance in relation to physical conditions and location within Danish stream systems. Hydrobiol 448: 217-228.

20. Chauhan M, Gopal B (2005) Vegetation structure and dynamics of a flood wetland along a subtropical regulated river. River Res Applic 21(5): 513-534.

21. Gopal B, Vass KK (2013) Impacts of regulation of river flows. In Gopal B (Ed.), Environmental flows. An introduction for water resources managers. National Institute of Ecology, New Delhi, India, pp. 81-112.

22. Assani AA, Petit F, Leclercq L (2006) The relation between geomorphologoical features and species richness in the low flow channel of the Warche, downstream from the Bütgenbach dam (Ardennes, Belgium). Aquat Bot 85: 112-120.

23. Langlade LR, Décamps 0 (1995) Plant colonization on rivers gravel bars: the effects of litter accumulation. CR Acad Sc Paris 317: 899-905.

24. Langlade LR, Décamps O (1995) Accumulation de limon et colonisation végétale d'un banc de galets. CR Acad Sc Paris 317: 1073-1082. 
25. Assani AA, Simard É, Gravel É, Ibrahim G, Campeau S (2013) The impact of "Man-made hydrological drought" on plant species abundance in the low flow channel downstream from the Matawin dam, Quebec. Water 5(3): 875-892.

26. Dubeau S, Assani AA, Ibrahim G, Rodriguez MA (2017) Temporal variability of streamflow and plant species abundance on islets as they relate to ENSO events downstream from an inversion-type reservoir. River Res Applic 33(9): 1411-1419.

27. Fortier C, Assani AA, Mesfioui M, Roy AG (2011) Comparison of interannual and interdecadal variability of heavy floods characteristics between upstream and downstream from Matawin dam. Rivers Res Applic 27(10): 1277-1289.

28. Assani AA, Buffin Bélanger T, Roy AG (2002) Analyse d'impacts d'un barrage sur le régime hydrologique de la rivière Matawin (Québec, Canada). Rev Sci Eau 15: 557-574.

29. Lajoie F, Assani AA, Roy AG, Mesfioui M (2007) Impacts of dams on monthly flow characteristics. The influence of watershed size and seasons. J Hydrol 334: 423-439.

30. Landry R, Assani AA, Biron S, Quessy JF (2014) The management modes of seasonal floods and their impacts on the relationship between climate and streamflow downstream from dams in Quebec (Canada). River Res Applic 30(3): 287-298.

31. Hey RD, Thorne CR (1983) Accuracy of surface samples from graveled material. J Hydraulic Eng ASCE 109(6) 842-851.

32. Kellerhals R, Bray I (1971) Sampling procedures for coarse fluvial sediments. J Hydraulic Eng ASCE 92(8): 1165-1181.

33. Marie Victorin FR, Brouillet L, Hay SG, Goulet I, Blondeau M, et al. (1995) In: Flore Laurentienne, ( $3^{\text {rd }}$ edn), Gaëtan Morin, Montréal, Canada.

34. Gauthier B (1997) Notes Explicatives sur la Ligne Naturelle des Hautes Eaux; Ministère de l'Environnement et de la Faune du Québec, Direction de la conservation et du patrimoine écologique: Québec, Canada.

35. Dagnélie P (1987) Théorie et méthodes statistiques. Les Presses Agronomiques de Gembloux, Gembloux, Belgique, vol 2.

36. Assani AA (2017) Analysis of the influence of the La Nina episode, land use and dam management modes on the characteristics of the 2008 spring freshet in Quebec (Canada). In: T Hromadka, P Rao (Eds.), Flood Risk Management, Intech, pp. 205-219.

\section{Your next submission with Juniper Publishers will reach you the below assets}

- Quality Editorial service

- Swift Peer Review

- Reprints availability

- E-prints Service

- Manuscript Podcast for convenient understanding

- Global attainment for your research

- Manuscript accessibility in different formats (Pdf, E-pub, Full Text, Audio)

- Unceasing customer service

Track the below URL for one-step submission https://juniperpublishers.com/online-submission.php 